\title{
Parasitoides de dípteros (inimigos naturais) coletados em fezes bovinas na região central do estado de Goiás.
}

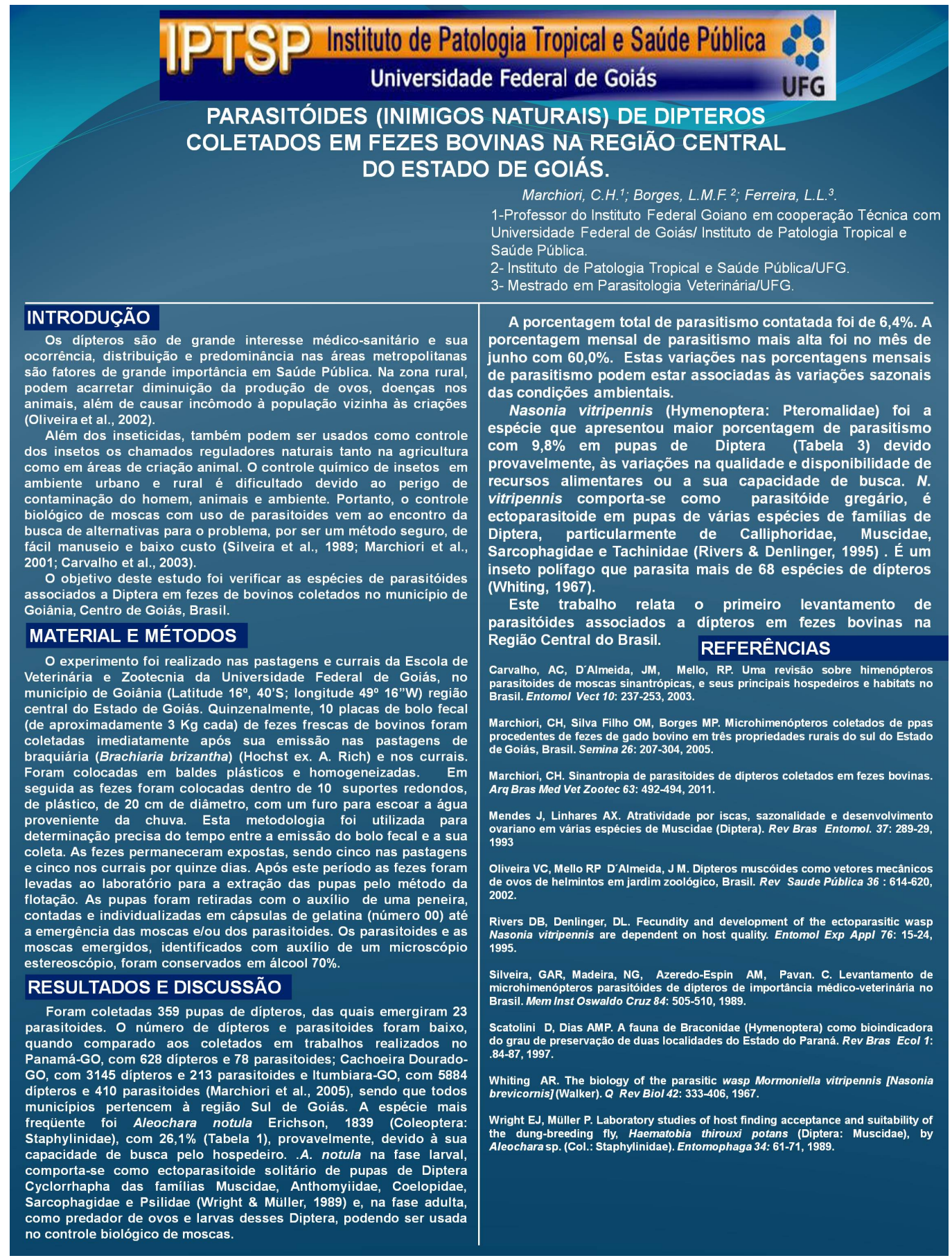


Figure 